\title{
Arisaema gracilentum, a new species of Arisaema (Araceae) from NE India
}

\author{
P. Bruggeman ${ }^{1}$
}

Key words

Arisaema

Arunachal Pradesh

Eastern Himalaya

new species
Abstract Arisaema gracilentum, a new species of Araceae, belonging to section Arisaema from the Lower Dibang Valley, Arunachal Pradesh State in NE India is described, illustrated and compared with related taxa.

Published on 29 June 2016

\section{INTRODUCTION}

The Indian state of Arunachal Pradesh lies in the Eastern Himalayas, one of the world's biodiversity hotspots (Myers et al. 2000). Owing to its large variety of habitats and the influence of the monsoon, Arunachal Pradesh has a very rich floristic diversity, accommodating nearly $50 \%$ of all known flowering plants in India (Rao \& Hajra 1986), and is listed as one of the 200 globally most important ecoregions. In contrast to the second biodiversity hotspot in India, the Western Ghats in S India, Arunachal Pradesh remains poorly studied. During the 19th century, several districts of Arunachal Pradesh were explored by famous plant hunters like Frank Kingdon-Ward (who entered from the Indian side of the border between India and Tibet) and Frank Ludlow and George Sheriff (entering from the Tibetan side) but the results of their expeditions provided only a glimpse of the true number of plant species still to be discovered in these remote mountains. While recent fieldwork by Western and Indian botanists has revealed an increasing number of new species of almost every genus present in Arunachal Pradesh, much of the state remains botanically unexplored owing to the inaccessible nature of the habitats, further hampered by seasonal landslides and poor roads leading to the remote corners. Continuing fieldwork is needed to further explore its rich biodiversity, especially the habitats of the more remote valleys near the borders, the alpine meadows and the mountain forests at higher altitudes.

As part of an on-going survey of the Arisaema from the Indian Subcontinent, the author undertook two fieldtrips to the Dibang district of Arunachal Pradesh State in September 2013 and May 2014. During these fieldtrips 10 different taxa of Arisaema were encountered in the Lower Dibang Valley in the area below the Mayodia Pass, and three on the forested slopes of the mountains surrounding Ainini in the Upper Dibang Valley. Given the relatively small area, the number of Arisaema species observed in the Lower Dibang Valley was unusually high, including representatives of five different sections: Arisaema rhizomatum C.E.C.Fish. and $A$. decipiens Schott from the autumn flowering section Decipienta; Arisaema petiolulatum Hook.f. from section Anomala; Arisaema nepenthoides Mart. and Arisaema wattii Hook.f. from section Nepenthoidea; and

\footnotetext{
Zwarte Ring 157, 1567 KK Assendelft, The Netherlands

e-mail: corybas66@hotmail.com.
}

Arisaema consanguineum Schott and A. concinnum Schott from section Sinarisaema; section Arisaema was represented by three taxa, Arisaema speciosum var. mirabile (Schott) Engl., and two that could not be identified. The status of the first of these unknown taxon is still under evaluation but the second taxon proved to be a rather unusual species which had a general habit similar to Arisaema speciosum (Wall.) Mart., yet flowered with an inflorescence unlike any of the currently recognized species from this section.

After careful comparison with all related taxa it was concluded to be new to science and its description is here given.

\section{TAXONOMY}

\section{Arisaema gracilentum Brugg., sp. nov. - Plate 1}

Most closely similar to $A$. speciosum (Wall.) Mart. but differing in having a lanceolate, hooked spathe with a constricted spathe mouth, and dark purple-banded inner spathe blade. - Type: P. Bruggeman PBR485 (holotype CAL prepared from cult., paratype $L$, prepared from cult.), India, Arunachal Pradesh State, Lower Dibang District, Mayodia, on slope near road, $2200 \mathrm{~m}$ asl.

Etymology. The species epithet, from the Latin adjective gracilentus, literally 'abounding in slenderness' refers to the graceful appearance of the inflorescence.

Plant seasonally dormant, up to $70 \mathrm{~cm}$ tall. Subterranean stem short, rhizomatous, cylindrical to ovate, up to $7 \mathrm{~cm}$ long, $4 \mathrm{~cm}$ diam with numerous dormant offsets. Roots white, branching with short side roots. Aerial shoot absent or inconspicuous. Cataphylls 2-3, up to $15 \mathrm{~cm}$ long, longest cataphyll often still enveloping the lower part of the inflorescence at anthesis. Leaf 1, blade often tinged purple underneath, dark green above. Petiole up to $70 \mathrm{~cm}$ long, up to $15 \mathrm{~mm}$ wide at base, 4-5 mm wide at the top, uniformly green, reddish, or minutely red-striated. Blade tri-foliolate, central leaflet broad elliptic, 20-30 cm long, 5-7 cm wide. Lateral leaflets elliptic-ovate, approximately equalling central leaflet, to $30 \mathrm{~cm}$ long, 6-8 $\mathrm{cm}$ wide, strongly asymmetrical. Inflorescence held below the leaf. Peduncle c. $10 \mathrm{~cm}$ long, green. Spathe tube pale green to green-beige tinged pink, sub-cylindrical to barrel-shaped, 5-6.5 $\mathrm{cm}$ long, $2.5-3 \mathrm{~cm}$ wide at base, narrowing to $1.5-2 \mathrm{~cm}$ below the mouth, spathe mouth constricted. Mouth margins revolute becoming strongly revolute along the midsection of the spathe blade. Spathe blade horizontal, lanceolate, ending in a sharp 

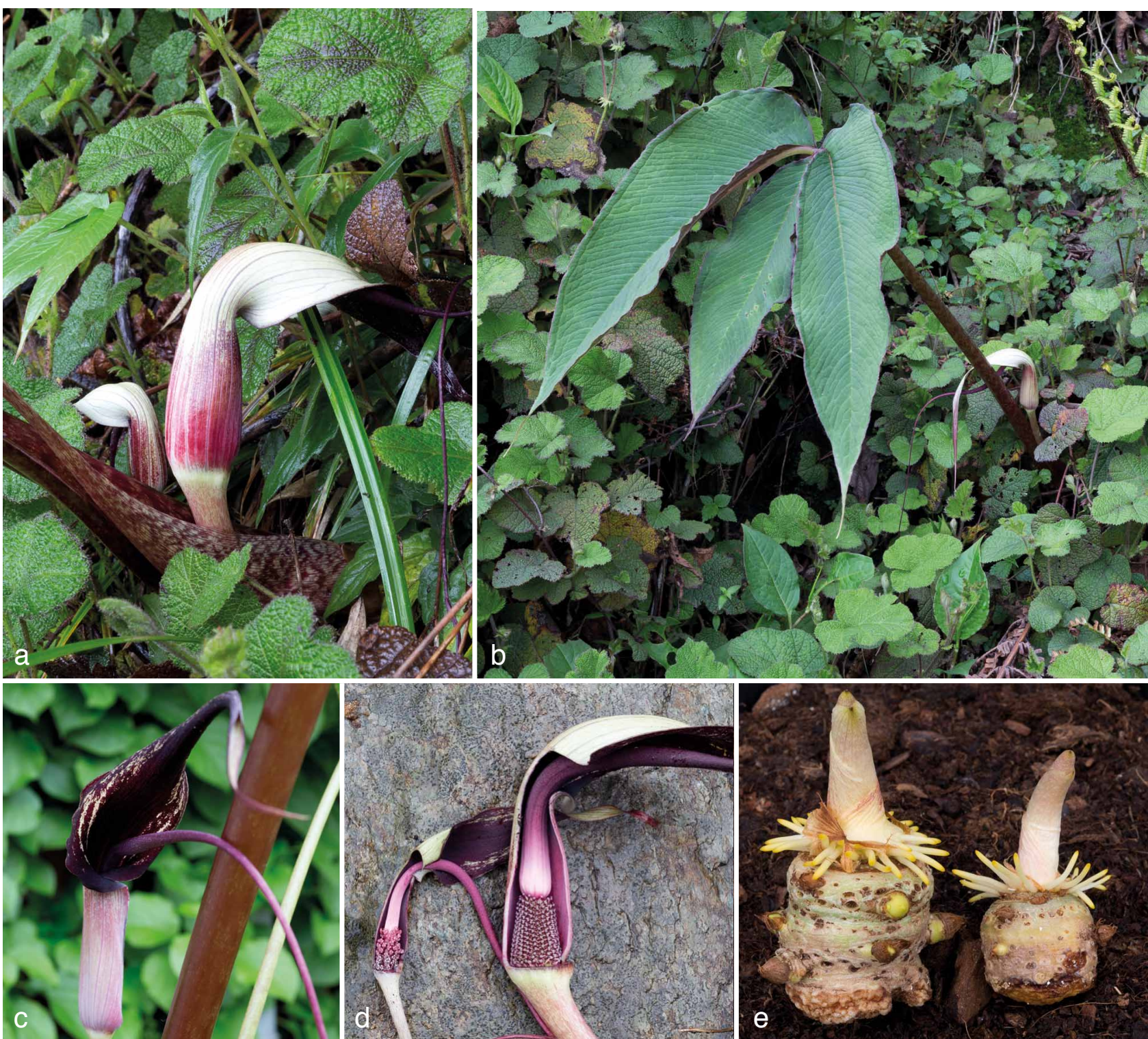

Plate 1 Arisaema gracilentum Brugg. a. Inflorescence side view; b. plant in situ; c. inflorescence front view; d. male and female spadix; e. underground stem.

tip, green-beige outside with a broad dark purple band inside slightly fading towards the edge. Spadix unisexual. Male spadix $2.5 \mathrm{~cm}$ long. Male fertile zone $2 \mathrm{~cm}$ long and c. $8 \mathrm{~mm}$ across. Synandria densely arranged, pale pink-purple, 3-4-androus, thecae dehiscent by an elongated pore, pollen white. Female spadix fertile zone $3 \mathrm{~cm}$ long and $2.5 \mathrm{~cm}$ across. Pistils densely arranged. Ovaries ovoid, green striped purple, $2.0-2.5 \mathrm{~mm}$ wide, stigma sessile, white. Spadix appendix sessile in male plants, sessile but with a slightly widened basal part in female plants, $100 \mathrm{~cm}$ long, exserted from the tube, base rugose, gradually tapering to a filiform thread.

Phenology - Flowering: April, May; fruiting: NovemberDecember.

\section{TAXONOMIC DISCUSSION}

The tri-partite leaf, short rhizomatous underground stem and long spadix appendix of Arisaema gracilentum show its close affinity to Arisaema speciosum and its varieties. In current literature the accepted classification for Arisaema speciosum splits this species into 3 varieties: var. speciosum, var. mirabile and var. ziroense (Gusman 2003).

Although the Dibang district borders Tibet and $A$. speciosum is reported from S Tibet by Li et al. (2010) in the Flora of China, their described form is similar to the forms observed in Nepal, $\mathrm{N}$ India (Sikkim, West Bengal) and Bhutan and would fall within the variational range of var. speciosum. In India the most easterly report of $A$. speciosum has been from the Upper Delei Valley in Lohit District of Arunachal Pradesh. It was described by Fisher as Arisaema speciosum var. truncatum from a specimen collected by Kingdon-Ward under number FKW8193. Based on the description and type this, however, falls within the variational range of var. speciosum too.

Arisaema gracilentum differs from all varieties of Arisaema speciosum by having a constricted spathe mouth and clear pale green-beige outside of the spathe blade with a contrasting dark banded zone inside. Additionally, it differs from $A$. speciosum var. speciosum by having a rugose appendix with a long and narrow, slightly recurved spathe blade and differs from var. ziroense by an inconspicuous pseudostem, smooth spathe surface, and much longer appendix. Arisaema gracilentum seems closest in general morphology to the Arunachal Pradesh form of var. mirabile and occurs in the same locality (var. mirabile emerges and flowers about a month later) but differs from it by lacking the abruptly thickened middle part of the appendix as well as having a longer and narrower spathe blade with a distinctly different colouring. The differences between Arisaema gracilentum and most similar taxa are summarized in Table 1. 
Table 1 Diagnostic differences between Arisaema gracilentum and all 3 varieties of $A$. speciosum.

\begin{tabular}{|c|c|c|c|c|}
\hline Character & A. speciosum var. speciosum & A. speciosum var. mirabile & A. speciosum var. ziroense & A. gracilentum \\
\hline $\begin{array}{l}\text { Spadix appendix surface } \\
\text { at midsection }\end{array}$ & Smooth & Rugose & Rugose & Rugose \\
\hline Spadix appendix shape & $\begin{array}{l}\text { Gradually thickened in the } \\
\text { middle part, filiform distally }\end{array}$ & $\begin{array}{l}\text { Abruptly thickened in the } \\
\text { middle part, filiform distally }\end{array}$ & $\begin{array}{l}\text { Narrowly conic to thickened in } \\
\text { the middle part, distal part } \\
\text { subulate }\end{array}$ & Narrowly conic, filiform distally \\
\hline Spadix appendix length & Up to 1 meter & Up to 1 meter & Up to $20 \mathrm{~cm}$ & Up to 1 meter \\
\hline Spathe limb shape & Ovate to deltoid, arching & $\begin{array}{l}\text { Deltoid to broad lanceolate, } \\
\text { often naviculate }\end{array}$ & $\begin{array}{l}\text { Broad lanceolate, often } \\
\text { naviculate }\end{array}$ & $\begin{array}{l}\text { Lanceolate with revolute } \\
\text { margins, hooked }\end{array}$ \\
\hline Pseudostem & Absent or inconspicuous & Absent or inconspicuous & Present, up to $20 \mathrm{~cm}$ & Absent \\
\hline Spathe tube shape & $\begin{array}{l}\text { Cylindrical with smooth outer } \\
\text { surface }\end{array}$ & $\begin{array}{l}\text { Cylindrical with smooth outer } \\
\text { surface }\end{array}$ & $\begin{array}{l}\text { Cylindrical with ribbed outer } \\
\text { surface }\end{array}$ & $\begin{array}{l}\text { Barrel-shaped, constricted at } \\
\text { the spathe mouth, smooth outer } \\
\text { surface }\end{array}$ \\
\hline Spathe blade colour & $\begin{array}{l}\text { Uniformly greenish brown to } \\
\text { purple-red with white longitudinal } \\
\text { lines }\end{array}$ & $\begin{array}{l}\text { Uniformly purple to red with } \\
\text { white longitudinal lines }\end{array}$ & $\begin{array}{l}\text { Uniformly purple with pale } \\
\text { white, almost translucent } \\
\text { longitudinal lines }\end{array}$ & $\begin{array}{l}\text { Pale green-beige outside, dark } \\
\text { purple-banded inside }\end{array}$ \\
\hline
\end{tabular}

\section{Additional note}

In the original diagnosis of $A$. speciosum var. ziroense (Gusman 2003) the spadix appendix at the midsection is mentioned as green and only the appendix base reported to be thickened to $6 \mathrm{~mm}$ diam. However, plants grown from seeds collected near the type locality at Ziro were identical in all key features except for having a much thicker (>10 mm), entirely purple rugose middle part of the appendix. This does not conform with the pictured and described plants, suggesting this taxon is more variable than the diagnosis suggests. It is, however, unclear from the publication whether the description was based on herbarium material, in situ population studies, or living material (collected as a sample from the holotype site) but plants identical to the seed grown rugose specimens from the holotype locality were observed by the author as far away as the upper Siang valley growing on a forested slope above Yingkiong, an area around $100 \mathrm{~km}$ to the east of Ziro.

\section{Conservational status}

Arisaema gracilentum has thus far only been observed growing on wooded slopes along a $4 \mathrm{~km}$ stretch of the road from Tiwari Gaon to Mayodia pass between 1700-2300 m altitude but not so far in other parts of Arunachal Pradesh. Estimated number of plants observed was around 100 with less than 25 mature plants. Considering the poorly studied status of the area, a listing of 'Data Deficient' (IUCN 2016) could be proposed, but as impending roadworks are threatening the type locality, a listing of this new species as 'Critically Endangered' is more appropriate.
Acknowledgements The author would like to express his gratitude to Wilbert Hetterscheid for carefully reading the manuscript and editorial suggestions.

\section{REFERENCES}

Gusman G. 2003. The intraspecific variation of Arisaema speciosum (Araceae). Systematics and Geography of Plants 73, 1: 63-70.

IUCN. 2016. Guidelines for using the IUCN Red List categories and criteria. Version 12. Prepared by the Standards and Petitions Subcommittee. Downloadable from http://www.iucnredlist.org/documents/RedListGuidelines.pdf. Li H, Zhu G, Murata J. 2010. Arisaema. Flora of China (text) 23: 43-69.

Myers N, Mittermeier RA, Mittermeier CG, et al. 2000. Biodiversity hotspots for conservation priorities. Nature 403: 853-858.

Rao RR, Hajra PK. 1986. Floristic diversity of Eastern Himalaya in a conservation perspective. Proceedings of the Indian Academy of Sciences (Animal Science/Plant Science) Supplement: 103-125. 